\title{
Male, Pale, and Stale? \\ Diversity in Lawyers' Leadership
}

Noel Semple*

\begin{abstract}
When lawyers elect the leaders of their self-regulatory organizations, what sort of people do they vote for? How do the selection processes for elite lawyer sub-groups affect the diversity and efficacy of those groups? This article quantitatively assesses the demographic and professional diversity of leadership in the Law Society of Upper Canada. After many years of underrepresentation, in 2015 visible minority members and women were elected in numbers proportionate to their shares of Ontario lawyers. Regression analysis suggests that being non-white was not a disadvantage in the 2015 election, and being female actually conferred an advantage in attracting lawyers' votes. The diverse employment contexts of the province's lawyers were also represented in the elected group. However, early-career lawyers were completely unrepresented. This is largely a consequence of electoral system design choices, and can be remedied through the implementation of career-stage constituencies. The Law Society's "benchers" are more demographically diverse than other elite lawyer sub-groups, such as judges, and the open and transparent selection process may be part of the reason.
\end{abstract}

Keywords: diversity, legal profession, legal services regulation, quantitative legal analysis, electoral system design

\section{Résumé}

Lorsque les avocats élisent les chefs de leurs organismes d'auto-réglementation, quel genre de leader choisissent-ils? Quelles sont les répercussions des processus de sélection des sous-groupes d'avocats élites en ce qui concerne la diversité et l'efficacité au sein de ces groupes? Le présent article effectue une évaluation quantitative de la démographie et de la diversité professionnelle du leadership du Barreau du Haut-Canada. Après de nombreuses années de sous-représentation, en 2015, des membres de minorités visibles et des femmes ont été élus dans une proportion représentative de leur importance dans la profession en Ontario. Une analyse de régression permet de conclure que, dans l'élection de 2015, ne pas être de race blanche nétait pas un handicap, et quêtre femme était avantageux en ce que cela

The author is grateful for the assistance of research assistants Myla Picco and Victor Wong, and for the assistance of Dan Edelstein (Academic Director, Windsor Research Data Centre).

Canadian Journal of Law and Society / Revue Canadienne Droit et Société, 2016, Volume 31, no. 3, pp. 405-427. doi:10.1017/cls.2016.33 
suscitait davantage de votes. La diversité des contextes d'emploi des avocats en Ontario était également bien représentée parmi les élus. Par contre, les avocats frais émoulus nétaient pas représentés du tout, du fait de décisions prises dans la conception du système de vote. Cet inconvénient peut être remédié par la création d'une catégorie correspondant aux étapes de carrière. Les conseillers au barreau du Barreau du Haut-Canada constituent un groupe plus diversifié sur le plan démographique que d'autres sous-groupes d'avocats élites, notamment les juges, ce qui pourrait relever en partie du processus de sélection ouvert et transparent.

Mots clés : diversité, profession juridique, réglementation des services juridiques, analyse quantitative, conception ces systèmes de vote

The importance of diversity is routinely proclaimed by leaders of the legal profession. ${ }^{1}$ Socio-legal scholars, testing these proclamations against reality, have evaluated the diversity of large corporate law firms, law schools, and the judiciary. ${ }^{2}$ However, similarly thorough study has not yet been made of diversity within the leadership of law societies and bar associations. ${ }^{3}$ These organizations are of central importance in North America's distinctive self-regulatory approach to legal services regulation. ${ }^{4}$ In addition to long-standing authority over who can be a lawyer, and over what lawyers must and must not do, lawyers' self-regulatory organizations increasingly bear responsibility for access to justice and for reconciling professionalism values with marketplace values. ${ }^{5}$

$1 \quad$ E.g. CBA Legal Futures Initiative, "Futures: Transforming the Delivery of Legal Services in Canada," (2014), http://www.cbafutures.org/cba/media/mediafiles/PDF/Reports/Futures-Final-eng. pdf (accessed 20 July 2016); American Bar Association, "Diversity and Inclusion," http://www. americanbar.org/diversity.html (accessed 20 July 2016).

2 See e.g. Elizabeth Chambliss, "Miles to Go: Progress of Minorities in the Legal Profession," (2004): 5-7, http://apps.americanbar.org/abastore/products/books/abstracts/4520014_2005\%20execsumm. pdf (accessed 20 July 2016); Faisal Bhabha, "Towards a Pedagogy of Diversity in Legal Education," Osgoode Hall Law Journal 52 (2015), digitalcommons.osgoode.yorku.ca/cgi/viewcontent. cgi? article $=2792 \&$ context $=$ ohlj (accessed 20 July 2016); Sabrina Lyon and Lorne Sossin, "Data and Diversity in the Canadian Justice Community," Journal of Law and Equality 11 (2014), http:// digitalcommons.osgoode.yorku.ca/cgi/viewcontent.cgi?article=1062\&context=olsrps (accessed 20 July 2016) [hereinafter Data and Diversity]; Jesse Rothstein and Albert H. Yoon, "Affirmative Action in Law School Admissions: What Do Racial Preferences Do?," University of Chicago Law Review 75 (2008): 649, http://www.nber.org/papers/w14276 (accessed 20 July 2016); Jason P. Nance and Paul E. Madsen, "An Empirical Analysis of Diversity in the Legal Profession," Connecticut Law Review 47 (2014): 271, http://connecticutlawreview.org/articles/an-empiricalanalysis-of-diversity-in-the-legal-profession/ (accessed 20 July 2016) [hereinafter An Empirical Analysis]; Avner Levin and Asher Alkoby, "Barriers to the Profession: Inaction in Ontario, Canada and Its Consequences," Oñati Socio-Legal Series 3 (2013): 580, http://papers.ssrn.com/sol3/papers. cfm?abstract_id=2283823 (accessed 20 July 2016).

3 However, see the American Bar Association's reports on progress towards its diversity goals: "Diversity and Inclusion," American Bar Association, (2015), http://www.americanbar.org/diversity. html (accessed 20 July 2016).

4 Common law jurisdictions elsewhere in the world have generally replaced self-regulation with state-dominated "co-regulation." Law societies and bar associations survive in Northern Europe and Australasia but with diminished status as "front line regulators." Noel Semple, Legal Services Regulation At The Crossroads: Justitia's Legions (Cheltenham, UK: Edward Elgar, 2015), 57-60.

5 John Pearson, "Canada's Legal Profession: Self-Regulating in the Public Interest?" Canadian Bar Review (2013): 555; Stephen Gillers, "How to Make Rules for Lawyers: The Professional Responsibility of the Legal Profession" Pepperdine Law Review 40 (2013): 365, http://papers.ssrn. com/sol3/papers.cfm?abstract_id=2218540 (accessed 20 July 2016); Semple, Justitia's Legions, ibid., 53-57. Regarding the importance of law societies and their governance, see Section 6, infra. 
When lawyers vote to elect the leaders of these self-regulatory organizations, what sort of people do they vote for? How representative of Ontario's diversity are the Law Society benchers? How does the selection process affect the diversity of self-regulatory leaders and other elite lawyer sub-groups? To respond to these queries, this article quantitatively assesses the demographic and professional diversity of leadership in Ontario's legal services self-regulator, the Law Society of Upper Canada (LSUC). Candidate campaign materials and voting pattern data from the five LSUC bencher elections since 1999 provide the data for the analysis. ${ }^{6}$

The results suggest that those who currently lead the Law Society (known as benchers) are not disproportionately "male and pale." Non-white members and women were elected in numbers proportionate to their shares of Ontario lawyers in the 2015 election. Regression analysis suggests that being non-white is not a disadvantage in these elections. ${ }^{7}$ Being a woman actually seems to confer a surprisingly significant advantage. ${ }^{8}$ This contrasts with the diversity situation in other elite subgroups of Canadian lawyers, especially the judiciary. The diverse employment contexts of the province's lawyers were also fairly well represented in the 2015 class of benchers. ${ }^{9}$ However one constituency-early-career lawyers-was completely unrepresented in the Law Society's elected leadership. ${ }^{10}$

This article begins by reviewing the literature on diversity, or lack thereof, in the legal profession and its regulatory leadership (Part I). The LSUC and its election system are introduced in Part II. The data source, hypotheses, and methodology for this study are discussed in Part III. The central empirical findings of this research, presented in Part IV, assess the diversity of the Law Society's elected leadership along dimensions of diversity: visible minority/ aboriginal status, practice context, gender, and career stage. Turning to the broader significance of these findings, Part $\mathrm{V}$ considers the effect of selection processes on the diversity of different elite legal subgroup groups. Part V also argues for career-stage constituencies in LSUC bencher elections, in order to position self-regulatory governance to better serve the public interest. Part VI summarizes and concludes.

\section{Diversity in the Legal Profession and Its Leadership}

Legal professionals in developed countries are usually less demographically diverse than the general populations from which they are drawn. For example, women and nonwhite people are generally under-represented among lawyers both in the United States ${ }^{11}$

Regarding the methodology of this study, see Section 3 and Appendix, infra.

Section 4(A), infra.

Section $4(\mathrm{C})$, infra.

Section 4(B), infra.

Section 4(D), infra.

In the United States, Hispanic and non-white Americans together constitute 33\% of the population but only $11 \%$ of practicing American lawyers. See United States Census Bureau, "USA QuickFacts from the US Census Bureau," http://quickfacts.census.gov/qfd/states/00000.html (accessed 20 July 2016). An additional 15.1\% of the American population identifies as white and Hispanic or Latino. Women are $51 \%$ of the American population but only $34 \%$ of practicing lawyers. See Nance \& Madsen, An Empirical Analysis, supra note 2, 287. 
and in Canada. ${ }^{12}$ Those who do become lawyers also often earn less money than their white male colleagues. According to Ronit Dinovitzer's Law and Beyond survey, troubling income divergences are already apparent just two years after Canadian lawyers are licensed. ${ }^{13}$ Black lawyers had a median income of $\$ 65,000$, compared with $\$ 78,200$ for other lawyer respondents. ${ }^{14}$ Female lawyers earned on average only 93 percent of men's salaries, just two years out. ${ }^{15}$

Diversity in legal positions that are better paid or considered elite often trails behind diversity in the profession at large. Women and non-white people seem to be "funnelled out" after becoming lawyers: they are less likely to be found in roles such as judge and large firm partner than they are among "rank and file" lawyers. This is apparently true in several world jurisdictions, ${ }^{16}$ including Canada. Of 2,160 Canadian judges analyzed in a recent study, only one percent were aboriginal and three percent were members of visible minorities. ${ }^{17}$ Women are also still significantly underrepresented in the judiciary, even relative to their share of the legal profession. ${ }^{18}$ Canada's large "Bay Street" corporate law firms are suspected in some quarters of a similar reluctance to diversify their top ranks, ${ }^{19}$ although reliable quantitative data are not yet available on this point. ${ }^{20}$

12 See The Canadian Bar Association, “CBA Legal Futures Initiative: Demographic Trends," (2013), http://www.cba.org/CBA-Legal-Futures-Initiative/Reports/Demographic-Trends (accessed 20 July 2016); The Law Society of British Columbia, "Towards a More Representative Legal Profession: Better Practice, Better Workplaces, Better Results,” (2012), https://www.lawsociety.bc.ca/docs/ publications/reports/Diversity_2012.pdf (accessed 20 July 2016).

13 Ronit Dinovitzer, "Law and Beyond: A National Study of Canadian Law Graduates," (2015), http://individual.utoronto.ca/dinovitzer/images/LABReport.pdf (accessed 20 July 2016).

14 Ibid., 63.

15 Ibid., 48.

16 See Asian Australian Lawyers Association Inc., "The Australian Legal Profession: A Snapshot of Asian Australian Diversity in 2015," (2015), https://aalavic.files.wordpress.com/2015/04/aalacultural-diversity-analysis-2015-infographic-final.pdf (accessed 20 July 2016); Nance and Madsen, An Empirical Analysis, supra note 2; Institute for Inclusion in the Legal Profession, "IILP Review 2014: The State of Diversity and Inclusion in the Legal Profession," (2014), http://www. theiilp.com/Resources/Documents/IILP_2014_Final.pdf (accessed 20 July 2016); Erika Rackley, Clare McGlynn, and Aoife O’Donoghue, “Diversity in the Legal Profession and Judiciary," https:// www.dur.ac.uk/resources/law/research/DiversityintheLegalProfessionandJudiciary.pdf (accessed 20 July 2016); Dina Medland, "Barriers to Entry: Diversity in Law Firms," http://www.ibanet.org/ Article/Detail.aspx?ArticleUid=5368a077-53b6-4377-8b12-8c58aad2a9ed (accessed 20 July 2016). Michael Tutton, "Canada must boost racial diversity in 'judiciary of whiteness', advocates urge," Toronto Star, July 18, 2016, https://www.thestar.com/news/queenspark/2016/07/18/canada-must-boost-racialdiversity-in-judiciary-of-whiteness-advocates-urge.html (accessed 20 July 2016); Andrew Griffith, "Diversity among federal and provincial judges," Policy Options, May 4, 2016, http://policyoptions.irpp. org/2016/05/04/diversity-among-federal-provincial-judges/ (accessed 20 July 2016). These proportions are well below their shares in the population at large: see section 4(A) infra.

18 Ibid. See also Rosemary Cairns Way, "Deliberate Disregard: Judicial Appointments under the Harper Government," The Supreme Court Law Review 67 (2014): 43, http://sclr.journals.yorku.ca/ index.php/sclr/article/view/39263 (accessed 20 July 2016); and Lyon and Sossin, Data and Diversity, supra note 2. As of July 2016, the last 22 individuals appointed to the Federal Court were all white. Cristin Schmitz, "Crampton wants Feds to Diversify Colours of Court," The Lawyers Weekly, July 22, 2016, http://www.lawyersweekly-digital.com/lawyersweekly/3560?folio=1\&pg=2 \#pg2 (accessed 22 July 2016).

19 David Doorey, "How Does a Bay Street Law Firm Make a List of Most Diverse Employers?" Law of Work Blog, February 21, 2012, http://lawofwork.ca/?p=4832 (accessed 20 July 2016); A Call to Action Canada, "Mission Statement," http://www.acalltoactioncanada.com/mission-statement (accessed 20 July 2016).

20 Lyon and Sossin, Data and Diversity, supra note 2, 102-05. 
Nevertheless, progress towards legal profession diversity has been made in parts of the world, especially at the entry level. In most developed countries, the newest cohorts of lawyers include approximately equal numbers of men and women. ${ }^{21}$ Proportionate representation has also been achieved by black and minority ethnic (BME) individuals among the solicitors and barristers of England and Wales ${ }^{22}$ and by Asian-born individuals among Australia's solicitors. ${ }^{23}$

Quantitative data can help us understand the profession's diversity challenges, successes and opportunities. ${ }^{24}$ This article therefore offers a quantitative diversity analysis of one elite lawyer sub-group: leaders of the Law Society of Upper Canada. The LSUC is the self-regulatory organization governing Ontario legal professionals.

Demographic dimensions of diversity such as gender, visible minority status, and aboriginal status are important in this context. As Faisal Bhabha notes, all of Canada's law societies including the LSUC have made institutional commitments to diversity along such demographic dimensions. ${ }^{25}$ However, professional dimensions of diversity, such as firm size and geographical location, are also relevant. Are sole practitioners, lawyers in firms of different sizes, and in-house corporate and government lawyers found in numbers proportionate to their numbers in the profession? How well are lawyers at different stages of their careers represented?

Demographic and professional diversity in regulatory leadership is a matter of equity, but also arguably a matter of professional vitality. Commentators have suggested that the robust form of self-regulation enjoyed by American and Canadian lawyers is at risk of being replaced by state-dominated "co-regulation," as it already has in the United Kingdom and Australia. ${ }^{26}$ Drawing on perspectives from a diverse group of leaders may strengthen lawyers' self-regulatory organizations. It can help them make better-informed decisions in the public interest, on specific discipline files but also on broader policy issues such as legal education, articling and licensing reform, and whether to permit non-lawyer investment in law firms.

Some legal self-regulatory organizations are diverse by constitutional design. The American Bar Association House of Delegates, for example, includes representatives of the Young Lawyers Division, the National Association of

$2147 \%$ of J.D. degrees in the United States are awarded to women. Re UK barristers see Bar Standards Board, "Called to the Bar Statistics," https://www.barstandardsboard.org.uk/media-centre/ research-and-statistics/statistics/called-to-the-bar-statistics/ (accessed 20 July 2016); Urbis, "2014 Profile of Solicitors of NSW Final Report," (March 2015), http://www.lawsociety.com.au/cs/ groups/public/documents/internetcontent/942948.pdf (accessed 20 July 2016).

See Solicitors Regulation Authority, "Staff Diversity Monitoring Data," http://www.sra.org.uk/sra/ equality-diversity/data/diversity-monitoring.page (accessed 20 July 2016) [hereinafter SRA Staff]; Bar Standards Board, supra note 21.

23 See Monica Tan, "Asian-Australian Lawyers Still Bump Up Against Legal Industry’s 'Bamboo Ceiling,"' The Guardian (April 27, 2015), http://www.theguardian.com/australia-news/2015/ apr/27/asian-australians-lawyers-still-bump-up-against-legal-industrys-bamboo-ceiling (accessed 20 July 2016); Urbis, "2014 Profile of Solicitors," supra note 21. Lyon and Sossin, Data and Diversity, supra note 2.

25 Bhabha, "Towards a Pedagogy of Diversity," supra note 2, 65. See also American Bar Association, supra note 3: "Goal III: Eliminate Bias and Enhance Diversity."

26 See Anthony E. Davis, "Regulation of the Legal Profession in the United States and the Future of Global Law Practice," The Professional Lawyer 19:1 (2009): 2, http://heinonline.org/HOL/ LandingPage?handle=hein.journals/proflw19\&div=3\&id=\&page $=($ accessed 20 July 2016); Richard E. Susskind, "Chapter 1," in Tomorrow's Lawyers: An Introduction to your Future (Oxford: Oxford University Press, 2013). 
Women Lawyers and the Solo, Small Firm, and General Practice Division among others. ${ }^{27}$ The Council of the Law Society of England and Wales includes seats representing groups such as the Black Solicitors' Network, the Child Care Law group, and the Junior Lawyers Division. ${ }^{28}$ By contrast the Law Society of Upper Canada, which is the focus of this article, ensures geographically diverse representation but leaves other dimensions of diversity to the candidates and the voters.

\section{The Law Society of Upper Canada}

Ontario's 51,000 licensed legal professionals are regulated by the LSUC. ${ }^{29}$ Compared with lawyers' self-regulatory organizations in other countries, the Law Society enjoys a hegemonic position in Ontario legal services regulation. ${ }^{30}$ It establishes entry, conduct, and business structure rules for legal professionals, and it exercises professional discipline, with minimal interference from either the government or the courts. ${ }^{31}$ Law Society membership is mandatory for all Ontario lawyers and licensed paralegals. ${ }^{32}$

The Law Society is led by "benchers," who assemble formally in "Convocation."33 Benchers serve part-time, in a role somewhat comparable to corporate directorship. ${ }^{34}$ Apart from the Attorney General (a provincial cabinet minister) and eight non-lawyers appointed by the government, the voting benchers are elected by licensed legal professionals. Five benchers are licensed paralegals, and forty are licensed lawyers. In addition to making major policy decisions and serving on disciplinary hearing panels, the benchers elect a Treasurer to serve as their President, and appoint a permanent Chief Executive Officer of the Law Society. ${ }^{35}$

\subsection{Law Society Bencher Elections}

The focus of this paper is the forty elected lawyer benchers, who make up approximately 75 percent of those eligible to vote on most Law Society decisions. ${ }^{36}$ Elections for lawyer benchers are held every four years, most recently in April of 2015.

27 See American Bar Association, "American Bar Association Constitution and Bylaws: Rules of Procedure House of Delegates," (2014), at section 6.2 and 6.8, http://www.americanbar.org/ content/dam/aba/administrative/house_of_delegates/aba_constitution_and_bylaws_2014. authcheckdam.pdf (accessed 20 July 2016).

See The Law Society (England \& Wales), “Council Constituencies," http://www.lawsociety.org.uk/ about-us/our-council/council-constituencies/ (accessed 20 July 2016) [hereinafter Council Constituencies]. Although the Law Society of England and Wales is not itself a regulator, its Council appoints the members of the Solicitors' Regulation Authority.

29 See Law Society Act, RSO 1990, c L.8, http://www.ontario.ca/laws/statute/90108 (accessed 20 July 2016) [hereinafter Law Society Act]. Ontario was known as "Upper Canada" prior to 1841, and the regulator's name is a vestige of that period. See The Law Society of Upper Canada, "About the Law Society," http://www.lsuc.on.ca/with.aspx?id=905 (accessed 20 July 2016). The 51,000 licensed professionals include 46,000 lawyers and 5,000 licensed paralegals. With the partial exception of Quebec, the law societies in other Canadian provinces enjoy similar powers.

31 Ibid., Justitia's Legions, supra note 4, 53-60.

32 Law Society Act, supra note 29.

33 Ibid., section 10.

34 Re compensation for benchers, see Yamri Taddese, "How much do benchers earn?" Law Times, August 27, 2015, http://digital.lawtimesnews.com/i/500799-april-27-2015/1\# (accessed 20 July 2016).

35 See Law Society Act, supra note 29, section 7.

36 Law Society Act, supra note 29, section 12-23. 
Any lawyer whose license has not been suspended may be a candidate, provided that he or she is nominated by five other lawyers. ${ }^{37}$ There is a term limit for elected lawyer benchers of twelve years (three terms). ${ }^{38}$

In the terminology of electoral design, lawyer benchers are elected under a multi-member, two-district plurality voting system. The electoral constituencies are based on geography. Each Ontario lawyer may vote for up to twenty candidates practicing law within the City of Toronto, and for up to twenty candidates practicing law elsewhere in the province. ${ }^{39}$ One distinctive feature of this electoral system is that while there are two districts (Toronto and non-Toronto), ${ }^{40}$ each voting lawyer can vote for up to twenty candidates from each district, regardless of where the voter resides. This ensures that non-Toronto candidates make up half of Convocation, which would otherwise be unlikely. ${ }^{41}$

In a further effort to ensure that all regions are heard from, a regional bencher provision was adopted in 1999. This system divides the province into eight regions, and designates the candidate practicing within each region who receives the most votes from the voters in that region as "Regional Bencher." ${ }^{42}$ The regional bencher provision does not add to the count of forty elected lawyer benchers, but it does ensure that Convocation will include lawyers from across the province.

However, the regional districts and constituencies also mean that non-Toronto candidates with relatively few votes are elected in lieu of Toronto candidates with significantly more votes. For example, in the 2015 bencher election, Fred Bickford was elected Regional Bencher for the sparsely-populated Northwest region of Ontario. ${ }^{43}$ Mr. Bickford received 101 votes from lawyers in that region, along with 778 votes from lawyers in the rest of the province for a total of 879 votes. ${ }^{44}$ By contrast, Toronto candidates Tanya Walker and Renatta Austin received 2,871 and 2,329 votes respectively but were not elected because they stood twenty-second and twenty-seventh within the Toronto district. ${ }^{45}$

37 See The Law Society of Upper Canada, By-Law 3, (2007), section 8(2), https://www.lsuc.on.ca/ WorkArea/DownloadAsset.aspx?id=2147484279 (accessed 20 July 2016) [hereinafter By-Law 3].

39 While Toronto is home to $21 \%$ of Ontario's population, $54 \%$ of the province's lawyers practice in this city. This probably reflects the concentration of corporate headquarters and public sector employers in the city. See Jamie Baxter and Albert Yoon, "The Geography of Civil Legal Services in Ontario" (November 2011): 36, http://www.lsuc.on.ca/WorkArea/DownloadAsset.aspx?id=2147486236 (accessed 20 July 2016).

40 See By-Law 3, supra note 37, section 6(1).

41 See section $5 \mathrm{~A}$, infra.

42 By-Law 3, supra note 37, section 6(4)(1).

43 See The Law Society of Upper Canada, “2015 Bencher Election Results," https://www.lsuc.on.ca/ uploadedFiles/2015-bencher-election-results.pdf (accessed 20 July 2016).

44 Ibid.

45 Ibid. Walker, however, was appointed to Convocation to fill the vacancy caused when Toronto bencher Paul Schabas became Treasurer in July 2016 (Alex Robinson, "First Black Female Bencher Elected in Toronto," Law Times July 11, 2016, http://www.lawtimesnews.com/201607115520/ headline-news/first-black-female-bencher-elected-in-toronto). Likewise, the candidate who stood $21^{\text {st }}$ in the Toronto election, Isfahan Merali, was appointed to Convocation to fill the vacancy caused when Toronto bencher Janet Minor became Treasurer. See The Law Society of Upper Canada, "Convocation - Election of Benchers," http://www.lsuc.on.ca/uploadedFiles/ For_the_Public/About_the_Law_Society/Convocation_Decisions/2015/convocation-may2015-consent.pdf (accessed 20 July 2016). 
Walker and Austin are both women in their first decades of practice, and they are both members of visible minorities. Their candidacies exemplify the apparently deleterious-although presumably unintended-effect that the regional constituency system has on other dimensions of diversity. This topic is further considered in Parts V and VI of the paper.

\section{Methodology}

\subsection{Data Source}

This analysis draws on data about 486 bencher candidacies from the five Law Society elections held since 1999. These data were obtained from the Law Society's election records and from bencher election candidate guides. ${ }^{46}$ The guides contain a one-page statement and a picture from each candidate in each election. A candidate's statement typically includes biographical information, policy proposals, and occasionally endorsements from individuals or organizations.

For each candidacy, the outcome measures were (i) whether or not the candidate was elected, and (ii) the candidate's vote share, expressed as a percentage. If a candidate had a 20 percent vote share in the 2015 election, that means her name was selected by 20 percent of all lawyers voting in that election. ${ }^{47}$ The average vote share among all 486 candidacies was 15.1 percent, and the average elected candidate had a vote share of 22.7 percent. Because of the regional constituency system described above, the elected candidates were not always those with the highest vote shares. ${ }^{48}$

The key independent variables were the various "dimensions of diversity" applicable to the candidates. These were (i) Region; (ii) Visible Minority / Aboriginal Status; (iii) Practice Context (firm size or employment status); (iv) Gender; and (v) Career Stage (for 2015 candidates only). A sixth independent variable, Name Recognition Proxy Measure, was added to help isolate the effects of the others. ${ }^{49}$ The research team gathered this information about each candidate from the candidate statements (supplemented, where necessary, by internet searches). Data were stored and analyzed in a FileMaker Pro database, in Excel spreadsheets, and in the SPSS statistical analysis package.

\subsection{Hypotheses}

The author formulated the five top-level hypotheses with regard to these data.

Hypothesis 1. Non-white people are funnelled out:

1a. in the process of becoming lawyers (they are less likely than white people are to be lawyers);

46 See The Law Society of Upper Canada "The Law Society of Upper Canada 1999 Bencher Election Guide for Voters"; "The Law Society of Upper Canada 2003 Bencher Election Voters' Guide"; "The Law Society of Upper Canada 2007 Bencher Election Voters' Guide"; “The Law Society of Upper Canada 2011 Bencher Election Voting Guide," http://www.lsuc.on.ca/WorkArea/DownloadAsset. aspx?id=2147484511; The Law Society of Upper Canada, "Voting Guide 2015 Bencher Election,"

47 https://www.lsuc.on.ca/uploadedFiles/bencher-election-2015-voting-guide.pdf (accessed 20 July 2016).

47 Vote share is a more useful measure of the support for a candidate than total number of votes received, because the total number of ballots cast varied significantly between elections.

48 Section 2(A), supra.

49 For further explanation of these variables, see the Appendix to this article. 
1b. in the bencher nomination process (they are less likely than white people are to be bencher candidates);

1c. in the bencher elections (they attract fewer votes than white candidates do).

Hypothesis 2. For those in private practice, the size of the firm in which a candidate practices is positively correlated with the candidate's vote share (candidates from larger firms get more votes).

Hypothesis 3. Women are funnelled out:

3a. in the process of becoming lawyers (they are less likely than men are to be lawyers);

3b. in the bencher nomination process (they are less likely than men are to be candidates for bencher);

3c. in the bencher elections (they attract fewer votes than male candidates do).

Hypothesis 4. Early-career lawyers are funnelled out:

4a. in the bencher nomination process (they are less likely than later-career lawyers are to be bencher candidates);

4b. in the bencher elections (they attract fewer votes than later-career candidates do).

Hypothesis 5. The status quo geographic constituency voting system reduces the demographic diversity of the elected benchers, compared with a hypothetical system in which the top vote-getters are elected regardless of where they practice.

\subsection{Analysis of Data}

Representativeness along the dimensions of diversity was analyzed by comparing each class of elected benchers with: (i) all candidates in that election, (ii) the population of Ontario lawyers at the time of the election, and (iii) the entire population of Ontario at the time of the election (where applicable). The effects of candidate characteristics on voter behaviour were estimated using ordinary linear regression, with candidate vote share as the dependent variable. This method estimates the effect of different candidate diversity attributes (e.g. being non-white or being a woman) on voters' willingness to support that candidate. ${ }^{50}$

Omitted variable bias and selection effects are possible problems with this method for estimating effects on voter behaviour. ${ }^{51}$ It could be that an unmeasured

50 Importantly, regression analysis estimates the effect of each independent variable, holding constant the other variables. For example, if the average female candidate receives more votes than the average male candidate, this might indicate a voter preference for female candidates. However, it might also reflect the fact that women are more likely than men to have some other characteristic (e.g. many years of experience as a lawyer) which makes them more appealing to voters, and the voters are indifferent to candidate gender. Regression analysis estimates the independent effect of gender while holding constant other variables such as years of experience.

51 Maxwell Palmer, "Does the Chief Justice Make Partisan Appointments to Special Courts and Panels?" Journal of Empirical Legal Studies 13 (2016): 153, http://onlinelibrary.wiley.com/ doi/10.1111/jels.12100/abstract (accessed 20 July 2016). 


\section{Noel Semple}

variable exerts an influence on voter behaviour and renders one or more of the apparent effects spurious. For example, female candidate gender appears to have a significant positive effect on voter support. ${ }^{52}$ The Name Recognition Proxy Measure data, described in the Appendix, was collected to test whether this was actually a consequence of differing levels of name recognition among male and female candidates. ${ }^{53}$ The regression analysis suggests that this is not the case. ${ }^{54}$ However, it remains possible that controlling for some other unknown variable would diminish or eliminate the effects reported here.

It is also important to note that the candidates were self-selected, not randomly selected, from the population of Ontario lawyers. This makes it conceivable that the candidates differ from the lawyer population in a manner that skews this study's results. Nevertheless, the results presented here illuminate voters' preferences in choosing among actual candidates, and there is no reason in particular to believe that the candidate sample is skewed in a meaningful way.

The regression results for all candidates in the five elections are presented in Table 1. Results that are statistically significant at the 0.05 level are in boldface. Part IV (below) will discuss the statistically significant findings from this regression analysis.

A separate regression analysis was performed of 2015 candidates (Table 2). For this group, two additional types of data were available: Name Recognition Proxy Measure and practice context. ${ }^{55}$

Table 1

Regression Analysis: All Candidates

\begin{tabular}{|c|c|c|c|c|}
\hline $\begin{array}{l}\text { Sample: All Candidates } 1999-2015(n=485 \\
\text { Dependent Variable: Vote Share Parameter }\end{array}$ & $\mathrm{B}$ & Standard Error & $\mathrm{t}$ & Significance \\
\hline Intercept & .225 & .013 & 17.401 & .000 \\
\hline Candidate Region $=$ Not Toronto & -.034 & .007 & -4.989 & .000 \\
\hline Candidate Region $=$ Toronto & $0^{\mathrm{a}}$ & & & \\
\hline Non-White Member = 0 (No) & .004 & .010 & .381 & .703 \\
\hline Non-White Member = 1 (Yes) & $0^{\mathrm{a}}$ & & & \\
\hline Candidate Female $=0(\mathrm{No})$ & -.040 & .008 & -5.329 & .000 \\
\hline Candidate Female = 1 (Yes) & $0^{\mathrm{a}}$ & & & \\
\hline Career Stage $=0-9$ years' experience & -.082 & .014 & -5.942 & .000 \\
\hline Career Stage $=10-19$ years' experience & -.060 & .009 & -6.528 & .000 \\
\hline Career Stage $=20-29$ years' experience & -.013 & .008 & -1.498 & .135 \\
\hline Career Stage $=30+$ years' experience & $0^{\mathrm{a}}$ & & & \\
\hline
\end{tabular}

${ }^{\mathrm{a}}$ This parameter is set to zero because it is redundant.

\footnotetext{
52 Infra, section $4(\mathrm{C})$.

53 The author speculated that the average female candidate might have better name recognition than the average male candidate, because little-known women are less likely than little-known men to run in these elections.

54 Infra, section $4(\mathrm{C})$.

55 See Appendix for an explanation of these variables.
} 
Table 2

Regression Analysis: 2015 Candidates

\begin{tabular}{|c|c|c|c|c|}
\hline $\begin{array}{l}\text { Sample: } 2015 \text { Candidates }(\mathrm{n}=95) \text { Dependent } \\
\text { Variable: Vote Share Parameter }\end{array}$ & B & Standard Error & $\mathrm{t}$ & Significance \\
\hline Intercept & .159 & .024 & 6.590 & .000 \\
\hline Candidate Region $=$ Not Toronto & -.014 & .010 & -1.325 & .189 \\
\hline Candidate Region $=$ Toronto & $0^{\mathrm{a}}$ & & & \\
\hline Non-White Member = 0 (No) & -.005 & .013 & -.388 & .699 \\
\hline Non-White Member = 1 (Yes) & $0^{\mathrm{a}}$ & & & \\
\hline $\begin{array}{l}\text { Candidate's Practice Context }=\text { Sole } \\
\text { Practitioner }\end{array}$ & .001 & .018 & .080 & .937 \\
\hline $\begin{array}{l}\text { Candidate's Practice Context }=\text { Small Firm } \\
(2-5 \text { Lawyers })\end{array}$ & .031 & .017 & 1.780 & .079 \\
\hline $\begin{array}{l}\text { Candidate's Practice Context = Medium Firm } \\
\quad(6-20 \text { Lawyers })\end{array}$ & .022 & .028 & .799 & .427 \\
\hline $\begin{array}{l}\text { Candidate's Practice Context = Large Firm } \\
(20+\text { Lawyers })\end{array}$ & .047 & .018 & 2.571 & .012 \\
\hline $\begin{array}{l}\text { Candidate's Practice Context = Employed in } \\
\text { Education }\end{array}$ & -.018 & .037 & -.491 & .624 \\
\hline $\begin{array}{l}\text { Candidate's Practice Context = Employed in } \\
\text { Government }\end{array}$ & .038 & .025 & 1.544 & .127 \\
\hline $\begin{array}{l}\text { Candidate's Practice Context = Employed in } \\
\text { Other Context }\end{array}$ & $0^{\mathrm{a}}$ & & & \\
\hline Candidate Female $=0$ (No) & -.069 & .011 & -6.180 & .000 \\
\hline Candidate Female = 1 (Yes) & $0^{\mathrm{a}}$ & & & \\
\hline Career Stage $=0-9$ years' experience & -.032 & .021 & -1.557 & .123 \\
\hline Career Stage $=10-19$ years' experience & -.018 & .014 & -1.316 & .192 \\
\hline Career Stage $=20-29$ years' experience & -.002 & .012 & -.131 & .896 \\
\hline Career Stage $=30+$ years' experience & $0^{\mathrm{a}}$ & & & \\
\hline Name Recognition Proxy Measure & .002 & .000 & 6.427 & .000 \\
\hline
\end{tabular}

${ }^{\mathrm{a}}$ This parameter is set to zero because it is redundant.

\section{Diversity in Regulatory Leadership and Voter Preferences}

\subsection{Non-White Status}

The 2015 election was either a historical anomaly, or a breakthrough for nonwhite candidates. The nine candidates who were elected constitute 22.5 percent of the total, which exceeds their share among Ontario lawyers (Table 3 and Figure 1). This figure remains below the 26.2 percent share that visible minorities and aboriginals together hold within Ontario's population according to the 2011 census.

The average vote share received by non-white candidates in 2015 exceeded the average share received by white candidates, while in previous elections the opposite was true. However, the regression analysis shows no statistically significant correlation between non-white status and vote share, either in 2015 or over all five 
416 Noel Semple

Table 3

Proportion Who Are Non-White

\begin{tabular}{|c|c|c|c|c|c|c|c|c|}
\hline Year & 1999 & 2003 & 2006 & 2007 & 2010 & 2011 & 2013 & 2015 \\
\hline Ontario Population & & & $24.84 \%$ & & & $27.00 \%$ & & $28.7 \%$ \\
\hline Ontario Lawyers & & & $18.00 \%$ & & $17.00 \%$ & & $16.90 \%$ & $17.30 \%$ \\
\hline Bencher Candidates (percent) & $9.52 \%$ & $10.80 \%$ & & $14.44 \%$ & & $18.87 \%$ & & $18.95 \%$ \\
\hline Bencher Candidates (number) & 8 & 11 & & 13 & & 20 & & 18 \\
\hline Elected Candidates (percent) & $5.00 \%$ & $7.50 \%$ & & $7.50 \%$ & & $7.50 \%$ & & $22.50 \%$ \\
\hline Elected Candidates (number) & 2 & 3 & & 3 & & 3 & & 9 \\
\hline
\end{tabular}

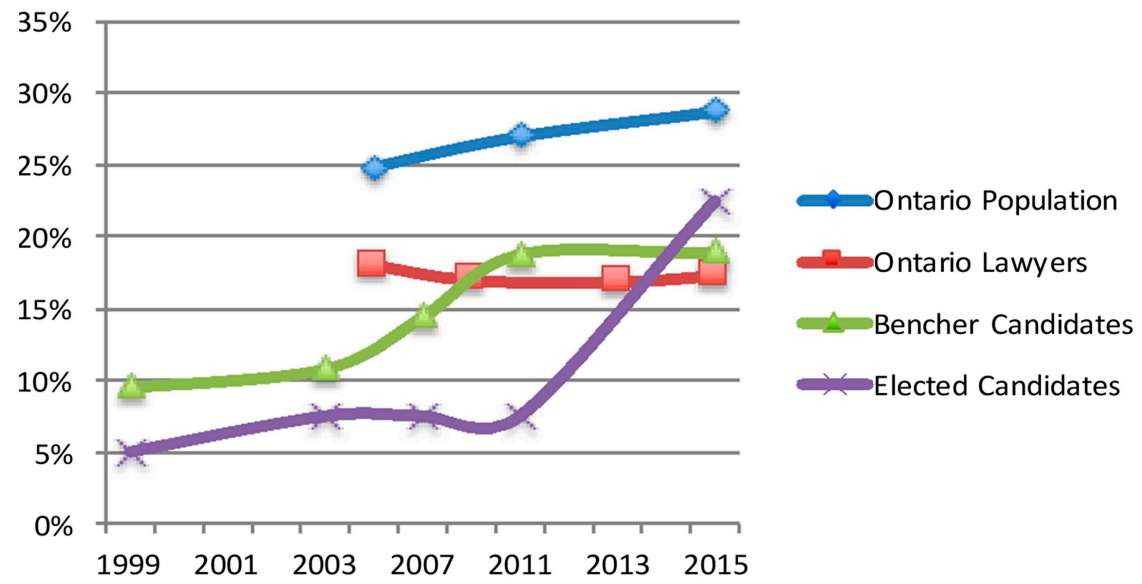

Figure 1 Proportion who are racial minority members.

elections (Figure 2). ${ }^{56}$ Thus, regarding the funnelling out of non-white individuals, hypothesis 1(a) cannot be rejected but hypotheses 1(b) and 1(c) can be rejected based on these data. ${ }^{57}$

\subsection{Practice Context}

Practice context is a "professional" dimension of diversity that many people want to see reflected in lawyers' self-regulatory leadership. Concerns have been raised about whether sole practitioners, corporate in-house counsel, and lawyers with non-litigation practices are appropriately included in Ontario's benchers. ${ }^{58}$ From this point of view, it is encouraging that the benchers elected in 2015 include some lawyers with each of the major employment statuses found in the Ontario bar (Figure 3).

$56 \quad$ See Table 1 , supra. $t_{(93)}=0.948726, p>.05$.

57 Section $3 \mathrm{~B}$, supra.

58 See Jennifer Brown, "Handful of Bencher Candidates Represent In-house Perspective," Canadian Lawyer Magazine (2015), http://www.canadianlawyermag.com/5510/Handful-of-benchercandidates-represent-in-house-perspective.html (accessed 20 July 2016); "Few Solicitors, Sole Practitioners at Convocation," Advocate Daily. April 2016, http://www.advocatedaily.com/ areas-of-law/few-solicitors-sole-practitioners-at-convocation.html. 


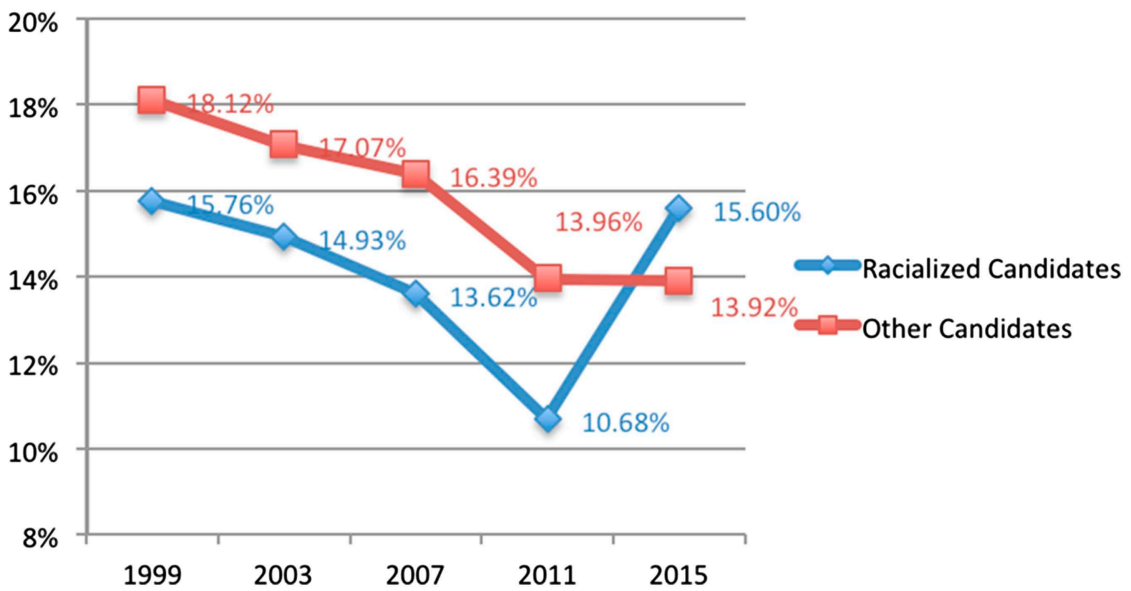

Figure 2 Average vote share by candidate status, 1999-2015.

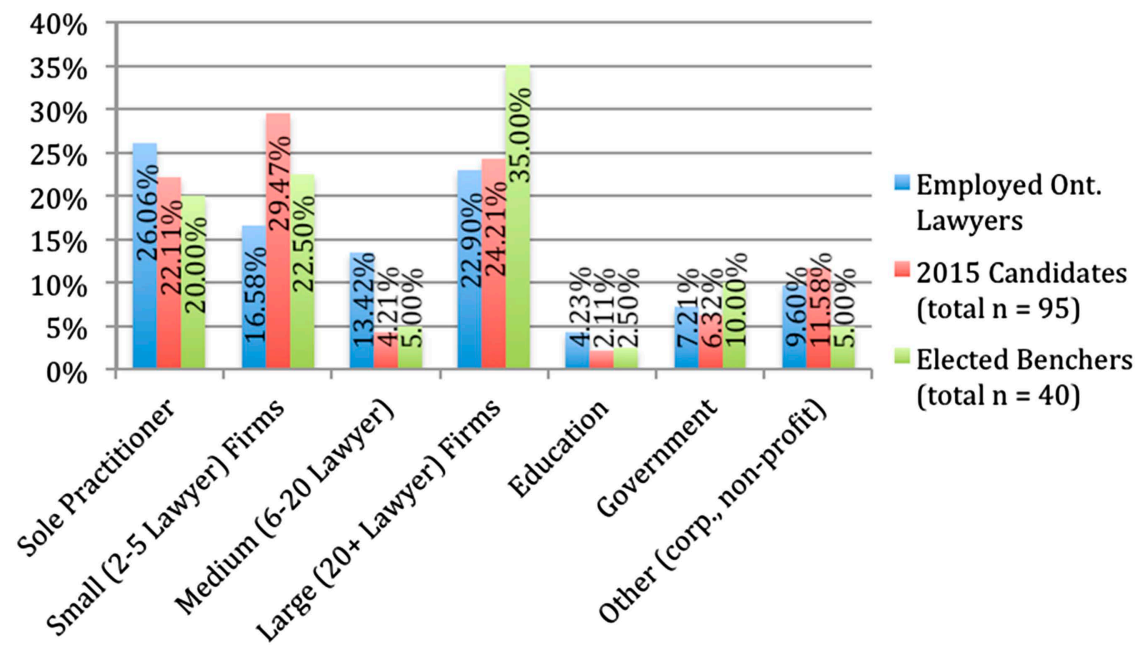

Figure 3 Proportion by employment context in 2014-2015.

That being said, the benchers are not perfectly representative along this dimension of diversity. No in-house corporate lawyers were elected. Lawyers practicing in firms larger than twenty are over-represented, with 22.9 percent of the province's lawyers but 35 percent of the benchers $(\mathrm{n}=14)$. According to the analysis in Table 2, practicing in a large firm (twenty or more lawyers) has a significant positive effect on vote share received. Meanwhile the medium-size firms (six to twenty lawyers) would require an additional three to four benchers to be proportionately represented, and sole practitioners would require an additional two to three benchers. However, there is no significant correlation between these other practice contexts and vote share. The data partially support hypothesis 2 regarding the correlation between firm size and vote share. ${ }^{59}$

59 Section 3B, supra. 


\subsection{Gender}

In the 2007, 2011, and 2015 elections, women were elected as benchers in numbers proportionate to their share of the Ontario legal profession. Table 4 shows the evolving gender balance over time. Of the 120 benchers elected over this period, 43.3 percent $(n=52)$ have been women. In 2013, women made up 41.9 percent of all Ontario lawyers (Figure 4), confirming hypothesis 3(a). ${ }^{60}$

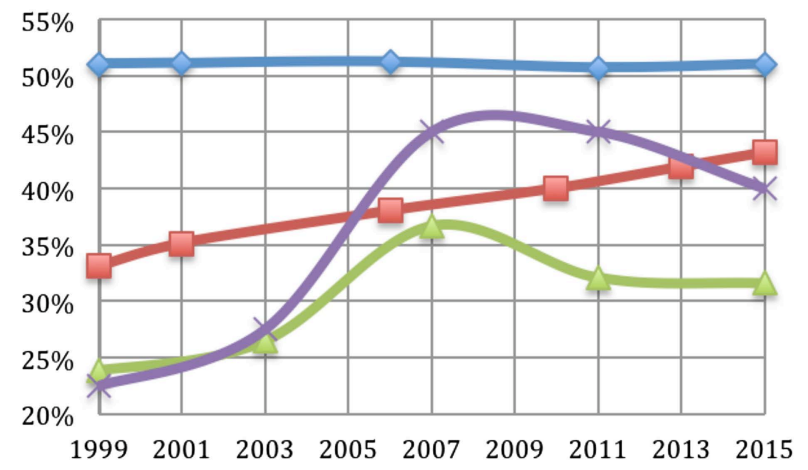

$\approx$ Ontario Population

$-\square$ Ontario Lawyers

- Bencher Candidates

$\rightarrow$ Elected Candidates

Figure 4 Proportion who are female.

Table 4

Proportion who are Female

\begin{tabular}{|c|c|c|c|c|c|c|c|c|c|}
\hline & 1999 & 2001 & 2003 & 2006 & 2007 & 2010 & 2011 & 2013 & 2015 \\
\hline Ontario Population & $51.02 \%{ }^{61}$ & $51.12 \%$ & & $51.23 \%$ & & & $50.70 \%$ & & $51.02 \%^{62}$ \\
\hline Ontario Lawyers & $33.10 \%{ }^{63}$ & $35.10 \%$ & & $38.00 \%{ }^{64}$ & & $40.00 \%{ }^{65}$ & & $41.90 \%{ }^{66}$ & $43.17 \%{ }^{67}$ \\
\hline Bencher Candidates & $23.81 \%$ & & $26.47 \%$ & & $36.67 \%$ & & $32.08 \%$ & & $31.58 \%$ \\
\hline Elected Candidates & $22.50 \%$ & & $27.50 \%$ & & $45.00 \%$ & & $45.00 \%$ & & $40.00 \%$ \\
\hline
\end{tabular}

60 Section 3B, supra. However, women outnumber men among Ontario law students and newly called lawyers. See The Law Society of Upper Canada, "Statistical Snapshot of Lawyers from the Lawyer Annual Report (LAR) 2013,” http://www.annualreport.lsuc.on.ca/2014/en/the-professions/ snapshots-lawyers.html (accessed 20 July 2016).

61 Projection, based on average of data from 2001, 2006, and 2011 censuses.

62 Projection, based on average of data from 2001, 2006, and 2011 censuses.

63 Projection based on statistic: $30.1 \%$ of all lawyers in Ontario identify as women as of 1996. See Michael Ornstein, "Lawyers in Ontario: Evidence From the 1996 Census: A Report for The Law Society of Upper Canada," http://www.lsuc.on.ca/WorkArea/DownloadAsset. aspx?id=2147487148 (accessed 20 July 2016).

64 See Michael Ornstein, "Fact Sheet: Racialization and Gender of Lawyers in Ontario," The Law Society of Upper Canada (2010), http://www.lsuc.on.ca/WorkArea/DownloadAsset.aspx?id=2147491863 (accessed 20 July 2016).

65 See The Law Society of Upper Canada "Statistical Snapshot of Lawyers in Ontario From 2010 Lawyer Annual Report,” (June 2012), http://www.lsuc.on.ca/WorkArea/DownloadAsset.aspx?id=2147488150 (accessed 20 July 2016).

66 See The Law Society of Upper Canada, "Statistical Snapshot of Lawyers from the Lawyer Annual Report (LAR) 2013," supra, note 60.

67 Projection, based on rate of growth 2006 to 2013. 
Consonant with hypothesis 3(b), women are less likely than men to be candidates, in these as in some other elections. ${ }^{68}$ However, exactly 50 percent of the 144 female candidates in bencher elections since 1999 were elected, compared with only 37.2 percent of the 341 male candidates. Female candidates have tended to attract more votes: an average vote share of 17.7 percent, compared with 14.7 percent for the average male candidate. ${ }^{69}$ The linear regression analyses show that gender has a significant effect after controlling for the other measured variables such as candidate name recognition and years of experience. They also show that the gender effect was larger in 2015 than it was in previous elections. ${ }^{70}$ Thus, hypothesis 3(c) (voter preference for male candidates) can clearly be rejected based on these data. ${ }^{71}$

\subsection{Career Stage}

Early-career lawyers make up the only group studied here that was significantly under-represented in the 2015 class of benchers. Those who had been practicing for less than fifteen years, who made up almost half of all Ontario lawyers at the time ( $45.31 \%$ of the total, $n=21,473)$, contributed only two of the forty benchers elected in 2015 (Figure 5). These two benchers had twelve and thirteen years of experience respectively. None of the benchers elected in 2015 were among Ontario's lawyers in the first decade of practice, who made up 25 to 30 percent of all lawyers in the province.

The under-representation of recent licensees is not a new phenomenon. Of the 200 benchers elected in the five general bencher elections since 1999, only six were

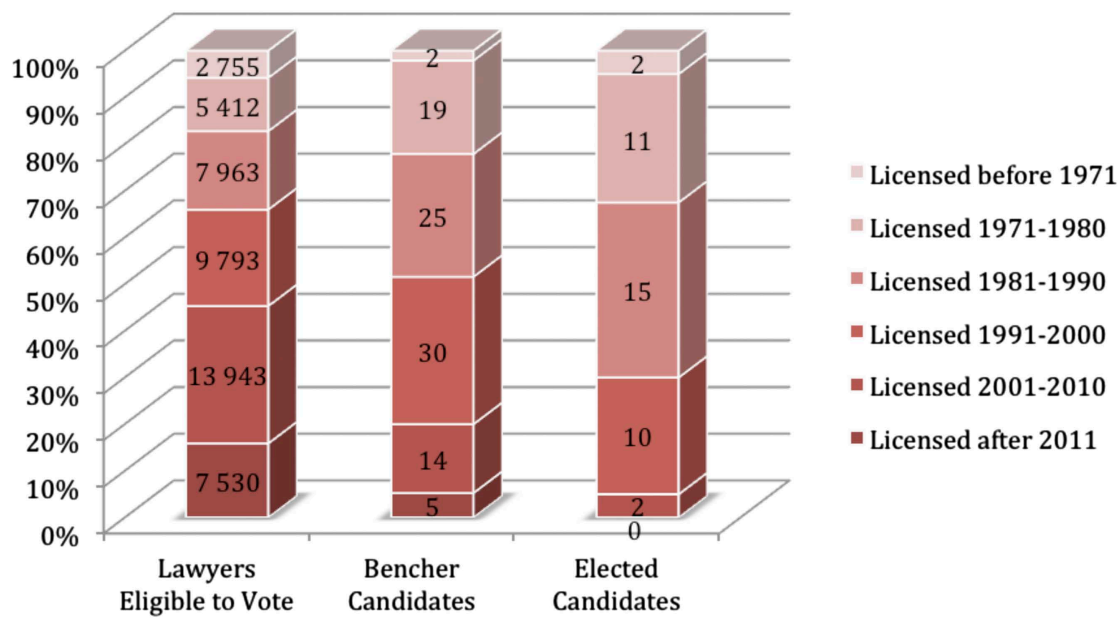

Figure 5 2014-2015 lawyers, candidates, and elected benchers by career stage.

\footnotetext{
68 Women were $43.17 \%$ of Ontario lawyers but only $31.58 \%$ of the bencher candidates in 2015. See e.g. Jennifer L. Lawless and Richard L. Fox, It Still Takes A Candidate: Why Women Don't Run For Office (Cambridge, UK: Cambridge University Press, 2010).

$t_{(485)}=3.814693, p<.05$.

Tables 1 and 2, supra.

Section 3B, supra.
} 
licensed less than ten years before they were elected. Moreover, two of these six had lengthy careers in other fields before being licensed as Ontario lawyers. The average bencher elected over this period had been licensed in Ontario for 27.53 years at the time of his or her election. ${ }^{72}$

\subsubsection{Why are recent licensees under-represented?}

On one level, the lack of early-career benchers is not surprising. Career stage is obviously correlated to age, and older individuals predominate in most elections. ${ }^{73}$ The average age of benchers is similar to the average age of Canadian members of parliament. ${ }^{74}$ Nevertheless, it is worth asking why there are not more early-career benchers, and the data offer some insights on this point.

The candidate pool is one factor. Since 1999, only 10 percent of the bencher candidates (an average of 9.8 candidates per election) have been in the first decades of their careers. In fact, the average career stage of candidates has increased steadily over this time, from 21.06 years post-license in 1999 to 24.53 years post-license in 2015. Thus, hypothesis 4(a) regarding funnelling out of early-career lawyers at the nomination stage is supported.

Voting patterns are also relevant. First-decade lawyers had an average vote share of 10.75 percent, compared with 16.04 percent for later-career candidates. Mean vote share per candidate climbs along with experience category, and the regression analysis for all five elections (Table 1 above) shows that those in the first two experience categories (zero to ten years and ten to nineteen years) received significantly fewer votes than their more experienced colleagues did. ${ }^{75}$ Voters in Law Society elections may perceive later-career candidates to have advantages such as life experience, career security, and the discretion to dedicate more time to the work of serving in Convocation.

However, in the 2015 candidate regression analysis, where name recognition data are included, the career-stage effect is no longer statistically significant. ${ }^{76}$ Thus, it is plausible that candidate experience has a less important effect on voter behaviour than does name recognition. If so, it is not necessarily (or not entirely) that voters prefer older candidates per se, but rather that they tend to vote for candidates whom they have heard of. Given that there is very little campaigning, name recognition will primarily be developed over time, and early-career candidates are less likely to enjoy this advantage. Thus the data only partially support hypothesis 4(b) regarding funnelling out of early-career lawyers at the vote-getting stage.

72 Nor are law students and apprentices (known as "articling students" in Ontario) included. While legal self-regulatory organizations such as the Law Society of England and Wales have constituency seats for these future lawyers, in Ontario they are allowed to neither vote nor serve as benchers. See The Law Society (England \& Wales), Council Constituencies, supra note 28.

73 See e.g. Brian Palmer, "Democracy or Gerontocracy: Is Congress getting older?" Slate, January 2, 2013, http://www.slate.com/articles/news_and_politics/explainer/2013/01/average_age_of_ members_of_u_s_congress_are_our_senators_and_representatives.html (accessed 20 July 2016). See Public Policy Forum "Edging Towards Diversity A Statistical Breakdown of Canada’s 41st Parliament, with Comparisons to the $40^{\text {th }}$ Parliament," (June 2011): 4, http://www.ppforum.ca/ sites/default/files/edging_towards_diversity_final.pdf (accessed 20 July 2016). 
The candidate pool and voter behaviour cannot entirely explain the lack of early-career lawyers in Convocation. First-decade lawyers received 6.86 percent of all the votes cast in the five elections since 1999, but made up only 3 percent of the benchers elected. The constituency system, which is explored in the next section of this paper, is a significant cause of the dearth of early-career lawyers in the Law Society's leadership.

\section{Elite Sub-Groups, Selection Processes, and Diversity}

In order to place the data in a broader context, this part asks what the findings can tell us about the relationship between selection processes and diversity. The consequences of the law society constituency system for bencher diversity are considered first. An argument for career-stage constituencies in legal self-regulator elections is then made in section 2 of part V. Finally, section 3 asks whether the relatively strong diversity of the 2015 benchers indicates a path toward greater diversity in other elite lawyer sub-groups such as judges.

\subsection{Law Society Bencher Election Constituencies}

As noted above, the current Law Society constituency system is based entirely on geography. It favours non-Toronto candidates, who need many fewer votes than their Toronto colleagues do to be elected. ${ }^{77}$ It is possible, however, to imagine alternatives that would have interesting effects on diversity. What if there were no geographic constituencies, and the top forty vote-getters in each election became benchers? As Figure 6 shows, under this “Top 40" system the leadership since 1999

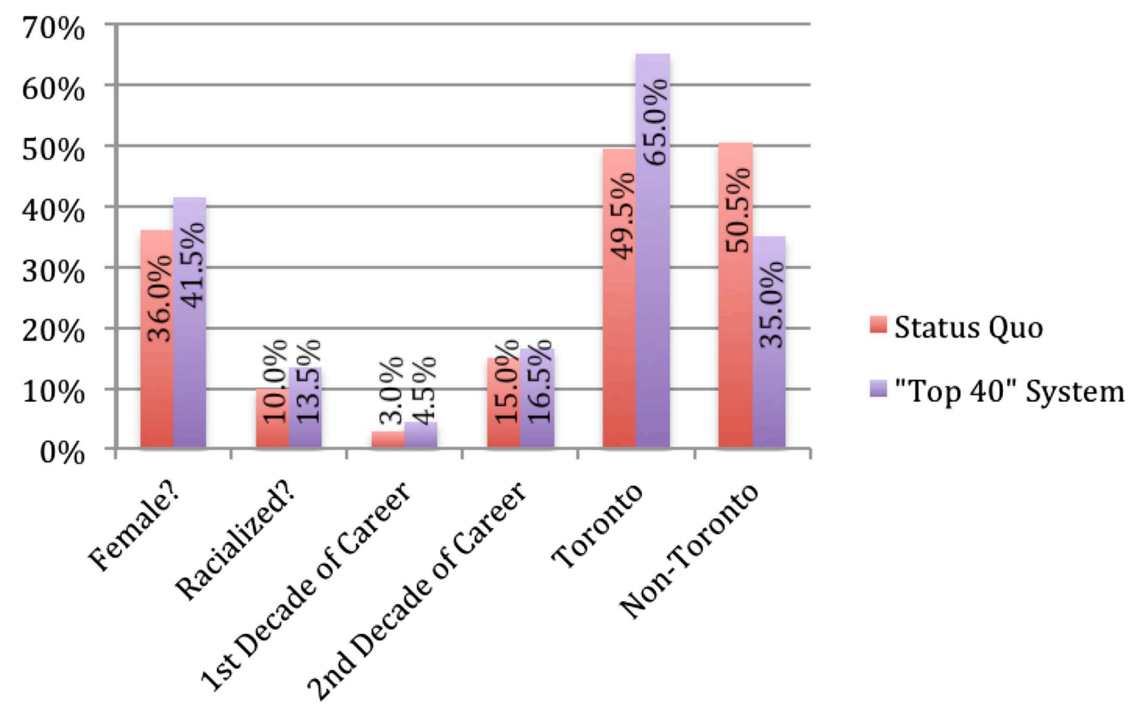

Figure 6 Benchers elected in past five elections under different constituency systems.

77 Section 2(A), supra. 
would have included more women, more visible minority lawyers, and more earlycareer lawyers. The number of non-white benchers elected would have increased most dramatically, from twenty to twenty-seven (Table 5). Thus, hypothesis 5 , regarding the effect of the status quo system on diversity, is clearly supported. ${ }^{78}$

The Top 40 system would have elected a more demographically diverse Convocation because female, non-white, and early-career candidates are more likely to run in Toronto than outside of the city. ${ }^{79}$ Tanya Walker and Renatta Austin, who ran in 2015 and would have been elected under Top 40, are examples. ${ }^{80}$ This system would also, arguably, better reflect the collective democratic will of Ontario's lawyers, insofar as candidates like Walker and Austin would be chosen instead of candidates who garnered less than half as many votes as they did.

Unfortunately, these benefits would come at the expense of geographic diversity. Over the five elections, Top 40 would have produced 130 out of 200 elected benchers practicing in Toronto, leaving non-Toronto lawyers under-represented relative to their numbers in the profession. Also, it is worth recalling that the status quo system did elect proportionate numbers of women and non-white lawyers in the 2015 election. ${ }^{81}$ Indeed, among the dimensions of diversity analyzed here, career stage is the only one for which the most recent class of benchers is significantly unrepresentative of Ontario's practicing bar.

\subsection{For Career-Stage Constituencies}

Introducing career-stage constituencies, as candidate Renatta Austin proposed, ${ }^{82}$ would fix this problem without undermining geographic diversity. The By-Laws could be amended to provide that each five-year career stage (lawyers with zero to

Table 5

Numbers of Benchers elected under status quo and "Top 40" systems

\begin{tabular}{lcc}
\hline & Status Quo Electoral System & “Top 40” System \\
\hline Female? & 72 & 83 \\
Non-White? & 20 & 27 \\
$1^{\text {st }}$ Decade of Careers & 6 & 9 \\
$2^{\text {nd }}$ Decade of Careers & 30 & 33 \\
Toronto & 99 & 130 \\
Non-Toronto & 101 & 70 \\
\hline
\end{tabular}

78 Section $3(\mathrm{~B})$, supra.

79 This, in turn, reflects broader demographic patterns in the province. See Dinovitzer, "Law and Beyond," supra note 13,61, regarding the greater demographic diversity in Toronto. Regarding the greater proportion of visible minority candidates in other elections in Toronto compared with the rest of the province, see Myer Siemiatycki, "The Diversity Gap: The Electoral under-Representation of Visible Minorities," (November 2011), diversecitytoronto.ca/wp-content/uploads/FinalReport.pdf (accessed 20 July 2016).

80 Section 2(A), supra. Walker was subsequently appointed to Convocation: note 45, supra.

81 Sections $4(\mathrm{~A})$ and (B), supra.

82 See "Renatta Austin," in The Law Society of Upper Canada, "2015 Bencher Election Results," supra note 43. Austin calls for eight Bencher seats to be reserved for those in their first 10 years. This paper proposes two seats for those in their first years and another two for those licensed 5-10 years. 
five years of practice; lawyers with five to nine years of practice; etc.) must be represented by at least two benchers, one from Toronto and one from elsewhere in Ontario. Like the Regional benchers, the "Career-Stage Benchers" would be the candidates in each constituency who received the most votes from within those constituencies.

Why should regulatory leadership include career-stage diversity? Legal services regulation should serve the public interest, ${ }^{83}$ and it should be client-centric as opposed to lawyer-centric. ${ }^{84}$ A regulator with career-stage diversity in its leadership can better meet these challenges. Early-career lawyers have first-hand insight into important regulatory policy issues such as legal education (including the effects of tuition and debt) and the licensing process. They are the only lawyers likely to be working as employed associates in private practice. They can therefore speak knowledgeably in leadership meetings about key issues like the ethical pressures of billable hour requirements and reconciling partners' demands with clients' interests. In the words of early-career candidate Renatta Austin:

Adapting the regulatory model to the needs of the $21^{\text {st }}$ century public, ensuring fair and equal access to the legal profession and cultivating a legal culture where diversity and inclusion are the norm, rather than challenges to be overcome, are policy issues that primarily impact the next generation of lawyers. Yet, we are largely excluded from the governance table. ${ }^{85}$

That early-career lawyers have valuable perspectives on regulatory issues is recognized by some within the Law Society. Twenty of the 2015 candidate statements made reference to special issues facing these lawyers, ${ }^{86}$ and Treasurer Janet Minor created a New Licensee Roundtable to hear from them. ${ }^{87}$ While this attentiveness is commendable, it would be even better to have the voices of early-career lawyers heard in a democratic way within the leadership boardroom.

Guaranteeing early-career lawyers a voice within self-regulatory governance would also plausibly increase their participation in these elections. Turnout in Law Society bencher elections has declined steadily from 56.0 percent in 1987 to only 33.84 percent in $2015 .^{88}$ In the 2015 election, only 31.02 percent of those licensed between 2001 and 2010 participated. ${ }^{89}$ Having the right to select one of their own to present their distinct perspective in Convocation could be a way to spark interest among relatively new lawyers.

It merits reiteration that failure to attract votes is not the only reason, or even the primary reason, why there are no early-career lawyers in Convocation. As noted above, under the pure democratic “Top 40" system, two lawyers in their first

Law Society Act, supra note 29, section 4.2(3).

Semple, Justitia's Legions, supra note 4, Chapter 9.

The Law Society of Upper Canada 2011 Bencher Election Voting Guide, supra note 46.

Ibid.

Janet Minor, "Moving Ahead to Enhance and Engage," Law Society of Upper Canada Gazette, June 25, 2015, http://www.lawsocietygazette.ca/treasurers-blog/moving-ahead/ (accessed 20 July 2016).

88 See The Law Society of Upper Canada, "2015 Election Results and Voter Turnout Statistics 19872015," at 42, https://www.lsuc.on.ca/uploadedFiles/2015-bencher-election-results-book.pdf (accessed 20 July 2016). 
decades of practice would have been elected in 2015, including Renatta Austin who was licensed in 2013.

If early-career lawyers are to have their own constituencies, then why shouldn't other groups such as in-house corporate counsel, non-litigating solicitors, or sole practitioners? ${ }^{90}$ In the words of bencher Raj Anand, "Once you start creating seats, it's difficult to know where to stop." system down a slippery slope towards an elaborate tokenism with numerous niche constituencies? The result might have little correspondence to the democratic will of the electorate as indicated by the top vote-getters.

The law society embarked down the road of compromising pure "at large" democracy in favour of broad representativeness when it created geographic constituencies. Perhaps the question should actually be, why stop travelling now? Constituencies promote diversity and good decision-making, albeit at the expense of deviation from the collective democratic will of the electorate. ${ }^{92}$ Travelling further down this road, representation could be based at least in part on communities of practice, defined by Lynn Mather et al. as "groups of lawyers with whom practitioners interact and to whom they compare themselves and look for common expectations and standards." 93 As noted above, groups such as the American Bar Association and the Law Society of England and Wales have a somewhat comparable system. ${ }^{94}$

Where exactly to stop on the road from pure democratic representation towards multiple constituencies is a question beyond the scope of this paper. The argument here is that, given the significant aspects of the public interest that earlycareer benchers could elucidate in Convocation, we should take at least this one further step down the road.

\subsection{Diversity of Benchers and other Legal Elites}

The process by which elite lawyer subgroups are selected seems to have consequences for the diversity of the groups. Notwithstanding the lack of early-career lawyers, the benchers elected in 2015 are significantly more diverse than other elite Canadian lawyer sub-groups. They are clearly more demographically diverse than

90 Tali Folkins, "Prof calls for reforms to boost youth presence at Convocation," Law Times, July 27, 2015, http://www.lawtimesnews.com/201507274832/headline-news/prof-calls-for-reforms-toboost-youth-presence-at-convocation (accessed 20 July 2016).

deviation than career-stage constituencies would.

93 Lynn M. Mather, Craig A. McEwen, and Richard J. Maiman, Divorce Lawyers at Work: Varieties of Professionalism in Practice (New York: Oxford University Press, 2001), 6. Regarding the importance of non-firm communities of practice, such as lawyer groups based on sexuality and gender, see Christine Parker, Just Lawyers: Regulation and Access to Justice (New York: Oxford University Press, 1999), 149-51. A specialty practice group such as criminal defence lawyers could also constitute a community of practice. The author has suggested "community of practice representation" for self-regulators, wherein "lawyers' communities of practice within a state or province could be recognized as constituencies, each of which would be entitled to elect representatives to the jurisdiction's bar association or law society.... Each licensee would be allowed to affiliate with one community of practice constituency, for the purpose of electing representatives to the central body." (Semple, Justitia's Legions, supra note 4, 294-96). 
the judiciary. ${ }^{95}$ They are also likely more diverse than large firm partners (although the data are less clear on that point).

Why are Ontario's benchers more demographically diverse than other elite sub-groups? Can any lessons be drawn for those who would like to see more diversity on the bench and in large firm partners' suites? Benchers are chosen in a transparent election, in which any Ontario lawyer in good standing can run and each Ontario lawyer has an equal number of votes. Judges and large firm partners, by contrast, are invited into their respective clubs after opaque, closed-door processes controlled by existing club members and other elite actors. Expanding the base of decision-makers, and increasing the transparency of the decision-making process, might bring more diverse talent into these other elite lawyer clubs. Transparency is favourable to diversity, as Lyon and Sossin among others have pointed out. ${ }^{96}$ The "diversity gap"- - between our benchers selected through transparent elections on one hand, and our judges selected through mysterious backroom consultations on the other-arguably illustrates the relationship between transparency and diversity.

\section{Conclusion}

The diversity of lawyers in positions of self-regulatory leadership is important for at least two reasons. First, these are "elite" positions within the profession that carry power and prestige (as well as time commitments and service obligations). It would be highly problematic in equity terms if male, and/or "pale," and/ or "stale" lawyers had preferential access to them. Second, it stands to reason that self-regulatory governance will work best when it can draw on the talents and perspectives of as many parts of the profession as possible.

Self-regulatory organizations and their governance matter. Admittedly, some still follow Max Weber and write self-regulatory organizations off as mere stalking horses for privileged occupational groups dedicated to "closure of social and eco-

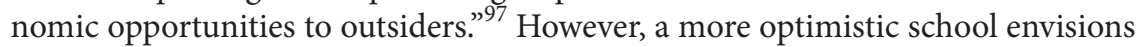
self-regulatory organizations creating opportunity, equity, and stability: not only for their diverse workers, but also for their diverse clientele and for society as a whole. $^{98}$ Across the common law world, legal self-regulatory organizations today

95 Supra notes 17-18 and accompanying text.

96 Lyon and Sossin, Data and Diversity, supra note 2; see also Lorne Sossin, "Transparency and Accountability Reflected in Tracking of Osgoode's Student Body," May 29, 2013, http://www. osgoode.yorku.ca/prospective-students/jd-program/life-osgoode/transparency-accountabilityreflected-tracking-osgoodes-student-body/ (accessed 20 July 2016).

Max Weber, Economy and Society: An Outline of Interpretive Sociology, eds. Guenther Roth and Claus Wittich, trans. Ephraim Fischoff, (1922; repr., New York: Bedminster Press, 1968) 342, 344. See also Richard Abel, American Lawyers (new ed. Oxford University Press: New York, 1989); Harry Arthurs, 'The Dead Parrot: Does Professional Self-Regulation Exhibit Vital Signs?', Alberta Law Review 33 (1995): 800, 802; Semple, Justitia’s Legions, supra note 4, 115-28.

98 Emile Durkheim, Professional Ethics and Civic Morals (trans. C. Brookfield [1890] Routledge: New York, 1992); Talcott Parsons, “The Professions and Social Structure," Social Forces 17, no. 4 (1939): 457, 463-64; Robert K. Merton, “The Functions of the Professional Association,” The American Journal of Nursing 58 (1958): 505; W.H. Hurlburt, The Self-Regulation of the Legal Profession in Canada and in England and Wales (Law Society of Alberta and Alberta Law Reform Institute: Calgary and Edmonton, 2000) 125; Eliot Freidson, Professionalism: The Third Logic (Polity Press: Cambridge, 2001); Semple, Justitia's Legions, supra note 4, 195-201; 287 et seq. 
take influential if not determinative positions on questions of legal education, access to the profession, and access to justice. The Law Society of Upper Canada, for example, is confronted with controversies about mandatory apprenticeship, ${ }^{99}$ paralegal scope of practice, ${ }^{100}$ and alternative business structures for law firms. ${ }^{101}$ From this point of view, it is clear that the diversity and quality of law society and bar association leadership is relevant not only to practitioners of law but also to all those for whom law is practiced.

It is therefore encouraging to find that the lawyer benchers of the Law Society of Upper Canada elected in 2015 are broadly representative of Ontario's legal profession in terms of gender, non-white status, and practice context. They are somewhat more "male" and "pale" than the general population, but no more so than the average Ontario lawyer. Only time will tell whether non-white candidates' strong performance in 2015 was a blip or a breakthrough, but being a woman has consistently conferred a significant apparent advantage to candidates in attracting votes. Other important dimensions of diversity, such as sexuality and socio-economic status, cannot be evaluated on the basis of these data.

Despite the apparent diversity success in terms of gender and race, the lack of early-career lawyers was a gaping hole in the 2015 Convocation. While not necessarily "stale," the average bencher was certainly in the middle or late stage of his or her career. Just as the lawyers of each region have the right to elect candidates from among themselves, lawyers in each five-year career-stage segment should be given the right to select two representatives to Convocation. This modest reform is arguably the last missing piece of the diversity puzzle at the Law Society. Introducing it now will help ensure that the Law Society can continue to confront its many challenges and opportunities as a robust and vital public interest regulator.

\author{
Noel Semple \\ University of Windsor Faculty of Law \\ Windsor, Ontario \\ noel.semple@uwindsor.ca
}

\title{
Appendix: Independent Variables for Statistical Analysis
}

The independent variables in this analysis are as follows:

(i) Candidate Region. As noted above, the province is divided into eight regions. Toronto is one of these, and twenty of the forty benchers are elected from Toronto.

(ii) Candidate Visible Minority or Aboriginal (yes/no). The team read each candidate statement. Based on the candidate's name, picture, and statement, each team

\footnotetext{
99 Wiseman, David. "The Law Society of Upper Canada and Access to Justice: Lessons from LawyerLicensing Reform." Windsor Yearbook of Access to Justice 31 (2013), http://ojs.uwindsor.ca/ojs/ leddy/index.php/WYAJ/article/view/4417 (accessed 27 July 2016).

100 Ministry of the Attorney General (Ontario). "Family Legal Services Review Consultation Paper (February 9, 2016)." Toronto: MAG (Ontario), 2016. http://www.attorneygeneral.jus.gov.on.ca/ english/family/legal_services_consultation_paper.html.

101 Law Society of Upper Canada, "Alternative Business Structures Working Group Report" (Toronto: LSUC, 2015), http://www.lsuc.on.ca/uploadedFiles/ABS-full-report.pdf.
} 
member indicated whether or not the candidate was, in the team member's opinion, either (i) a member of a visible minority as defined by Statistics Canada, ${ }^{102}$ or (ii) a member of an aboriginal group. Candidates meeting either one of these criteria, according to a majority of the three raters, were coded as non-white. ${ }^{103}$

(iii) Candidate's Practice Context. The following practice categories, used by the Law Society in its statistical reporting, were also used in this study: (1) Sole Practitioner; (2) Small Firm (2 to 5 Lawyers); (3) Medium Firm (6 to 20 Lawyers); (4) Large Firm (20+ Lawyers); (4) Employed in Education; (5) Employed in Government; and (6) Employed in Other Context (including corporate and non-profit sectors).

(iv) Candidate Female (yes/no). This was also coded by team members based on reading the statements and looking at the accompanying pictures.

(v) Career Stage (2015 candidates only). The year in which the candidate was first licensed to practice law in Ontario was subtracted from the year of the election to give the candidate's years of experience at the time of the election. ${ }^{104}$ Years of experience were aggregated into career-stage categories: (1) 0 to 9 years; (2) 10 to 19 years; (3) 20 to 29 years; (4) 30+ years.

(vi) Name recognition proxy measure (NRPM) (2015 candidates only). This measure included (i) the number of times the candidate had been mentioned in the two trade newspapers for Ontario lawyers, and (ii) the number of times the candidate's name appeared in AccessCLE, which is the Law Society's database of continuing legal education articles and presentations. ${ }^{105}$ For each of the 2015 candidates, the number of hits from these sources prior to election day in 2015 was tallied. The reasoning behind this proxy measure is that the more often a candidate's name appeared in an Ontario legal trade newspaper, and the more often he or she spoke at events for Ontario lawyers, the more likely it is that his or her name would have been recognized by voters reviewing the bencher election ballots. NRPM is not a dimension of diversity. However, as explained above, ${ }^{106}$ it is correlated with vote share and its use strengthens the study's conclusion about the effects of gender.

102 "This category includes persons who are non-Caucasian in race or non-white in colour and who do not report being Aboriginal." (Statistics Canada, "Classification of Visible Minority," (2015), http://www.statcan.gc.ca/eng/concepts/definitions/minority01a.) (accessed 20 July 2016)

This method may categorize some candidates in a manner different than how they would self-identify.

104 In those cases where this information was not part of the statement, it was sought on the internet. In a few cases (fewer than 15) where the information was not available online, the candidate's year of license was guessed based on his or her picture and the assumption that the license was received when the candidate was 26 years old. (accessed 20 July 2016).

106 Section 4C, supra. 